\title{
SCORPION STINGS IN TURKEY: EPIDEMIOLOGICAL AND CLINICAL ASPECTS BETWEEN THE YEARS 1995 AND 2004
}

Yıldırım CESARETLI(1) \& Ozcan OZKAN(1)

\begin{abstract}
SUMMARY
The most important health-threatening scorpions found in Turkey are; Androctonus crassicauda, Leiurus quinquestriatus, Mesobuthus gibbosus and M. eupeus species, all of which belong to the Buthidae family. The epidemiological and clinical findings of scorpion stings in Turkey were evaluated between the years 1995 and 2004 based on data recorded in the National Poison Information Center (NPIC). A total of 930 cases were recorded. The cases mostly occurred in the month of July. The gender distribution was $50.22 \%$ female and $45.48 \%$ male. It was shown that the 20-29 age group presented more scorpion stings. Most of the stings occurred in Central Anatolia and Marmara regions of Turkey. Patients at the hospital showed signs of localized (pain, hyperemia, edema and numbness) and systemic effects (hyperthermia, nausea and vomiting, tachycardia, shivering and lethargy) but no lethality was notified. According to records, 33\% of the poisoned patients were treated with antivenin in healthcare facilities.
\end{abstract}

KEYWORDS: Scorpion sting; Poisoning; Epidemiology; NPIC; Turkey.

\section{INTRODUCTION}

Scorpions contain concentrates of biologically active substances developed to block vital physiological and biochemical functions of the victim. Scorpion poisoning is a life-threatening emergency and causes serious health problems in tropical and subtropical regions, especially in north Africa, Latin America, India, and the middle East. Clinical reports of victims stung by scorpions describe cardiac dysfunction and respiratory failure that can be fatal $2,17,26,34$.

Different approaches to the treatment of scorpion poisoning have been advocated by different investigators. Some of them recommend treatment of mild cases of poisoning with symptomatic measures and/ or antivenin ${ }^{20}$ and severe cases with symptomatic measures, support of vital functions and IV injection of antivenin ${ }^{2,20}$.

Epidemiologic data are scarce due to under-declaration of cases and the insufficiency of studies devoted to scorpion stings. Two factors may explain the deficiency of information: the generally reduced severity of scorpion poisoning in adults, and the organization of health services, which do not require very precise information ${ }^{8}$. Therefore, the national poison information services or centers have an important role to pay attention to physicians or patients in case of scorpion poisoning. In Turkey, the National Poison Information Center (NPIC) was established in the Refik Saydam Public Health Agency (RSPHA) of the Ministry of Health (http://uzem.rshm.gov.tr) in 1986. It works 24 hours a day, having done so since 1988 .
The aim of this study was to classify and characterize scorpion stings among inquiries to the National Poison Information Center between the years 1995 and 2004, in regard to the epidemiology and clinical symptomatology.

\section{PATIENTS AND METHODS}

Data collection: The NPIC was established in 1986 and is accessible on a 24/7 basis. Clinicians in Turkey encountering victims of scorpion poisoning are required to report the cases to the NPIC. For this study, only cases involving scorpion poisoning in the NPIC database between the years 1995 and 2004 were investigated.

Epidemiological and clinical data: Clinical and epidemiological data were obtained from the NPIC database. The data were evaluated according to the patients' age, gender, day of sting, admission to the healthcare facility, clinical symptoms (localized and systemic) and condition of the patients and treatment.

Clinical assessment of poisoning and treatment: Clinical assessment of all registered cases was conducted based on recorded occurrences submitted by local physicians. Patients were classified into two major groups based on observed symptoms. The localized signs group had symptoms including localized pain hyperemia, burning and itching. The systemic signs group had symptoms that are outlined in Table 2. Patients were further divided by the health professionals into those with either no, mild, moderate, or severe poisoning, according to

(1) Refik Saydam Public Health Agency, 06100, Ankara/Turkey.

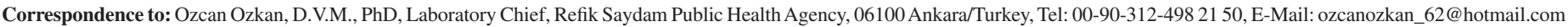


the clinical features. Mild poisoning was characterized by localized signs (pain, edema), and localized sweating; moderate poisoning by localized signs, and systemic poisoning (manifestations such as sialorrhea, sweating, nausea, vomiting, abdominal pain, tachycardia, tachypnea, mild hypertension, agitation, drowsiness), and severe poisoning was characterized, besides the moderate signs, by stupor or coma.

Statistical analysis: Data of patients were analyzed with SPSS software, using the Pearson's chi-square method. Values obtained were considered to be significantly different if $p<0.05$.

\section{RESULTS}

We compiled all cases reported in Turkey of human scorpion stings between 1995 and 2004. Among the gross total of reported poisoning cases of various origin $(129,548), 1,929(1.5 \%)$ of all incidents involved animal bites and stings, of which 930 (48.2\%) were scorpion stings.

Epidemiological data: The accidents occurred in all regions of Turkey. The majority of the incidents happened in the Central Anatolia region and in the Marmara region (Fig 1).

Most of the cases (54.95\%) were notified during the summer period, as shown in Fig 2. The monthly distribution of cases of scorpion stings was $14.95 \%$ in May, $14.95 \%$ in June, $20.43 \%$ in July, $19.57 \%$ in August and $12.37 \%$ in September (i.e. mainly distributed between the months of May and September), with a peak in July (Fig. 2).

The gender distribution of the victims is $50.22 \%$ female and $45.48 \%$ male. Scorpion stings also have been mostly seen in male patients between
0-19 age groups. On the other hand, female were more liable to scorpion sting than men, in patients aged 20 and over. There was a statistically

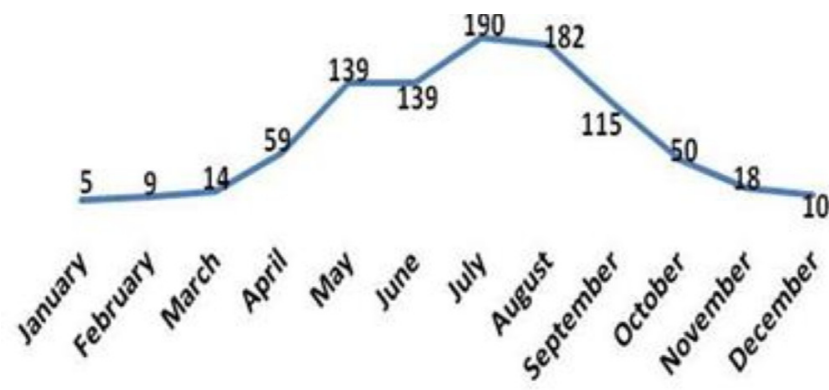

Number of cases

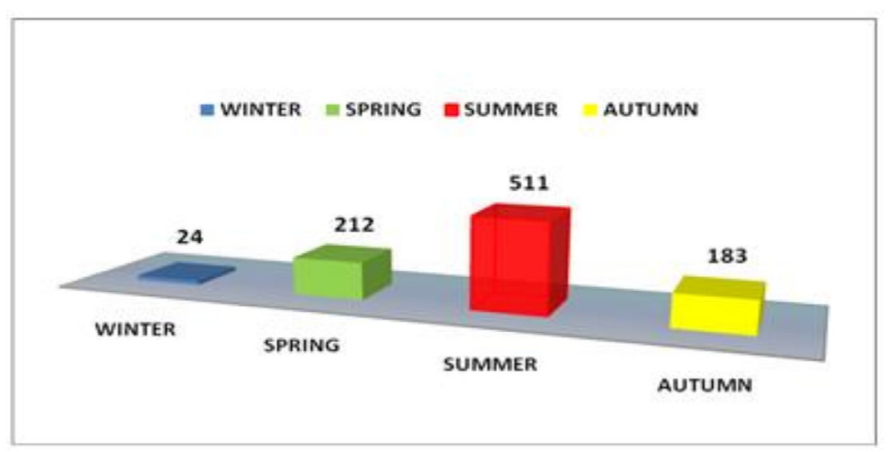

Fig. 2 - Distribution of scorpion stings according to months and seasons.

\section{GEOGRAPHIC REGIONS OF TURKEY}

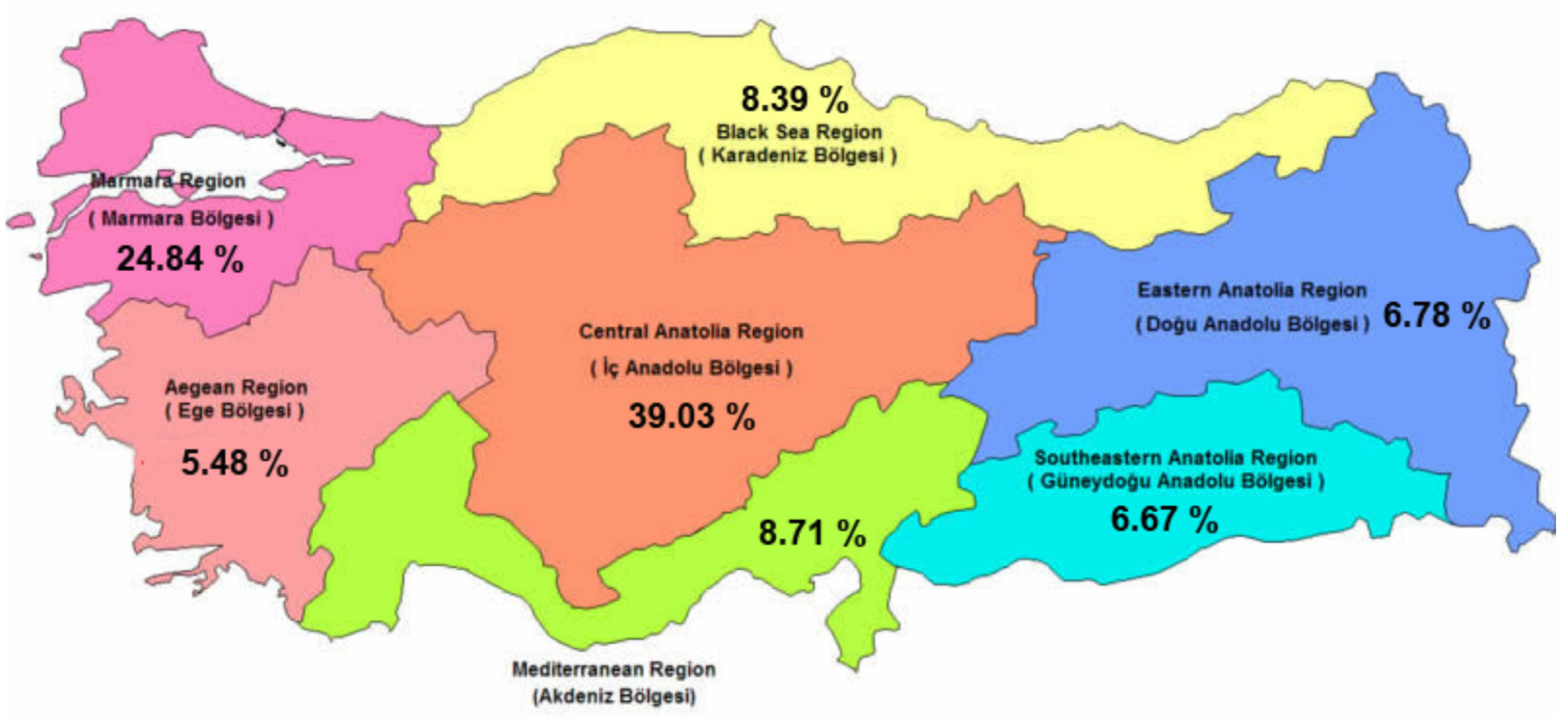

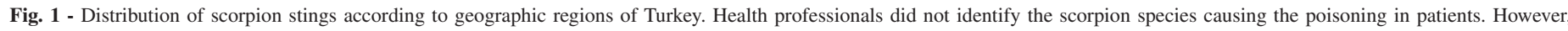

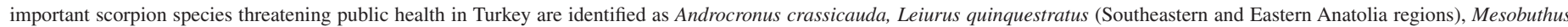

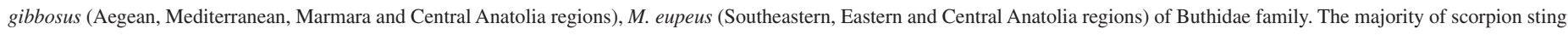
cases were in the Central Anatolia region and the Marmara region. 
significant association between age groups and sexes $(p<0.01)$. The age distribution of the patients is displayed in Table 1 . With respect to the age, it is shown that the 20-29 age group presented more scorpion stings $(23.55 \%)$ than the other groups. The notification records indicated that most of the stung patients arrived at the hospital in a time ranging between one to three hours after the sting (89.39\% of the patients) (Table 1).

Clinical assessment of the poisoning and treatment: The most common symptoms of scorpion sting are shown in Table 2. Scorpion stings caused both localized and systemic effects. Localized symptoms were observed in $77.93 \%$ of the cases, as localized pain $(47.58 \%)$,

Table 1

Epidemiological characteristics of patients stung by scorpions

\begin{tabular}{lccccc}
\hline \multicolumn{3}{c}{ EPIDEMIOLOGICAL CHARACTERISTICS } \\
\hline & & Gender & \multicolumn{3}{c}{$\begin{array}{c}\text { Number of patients } \\
\text { (n: 930) }\end{array}$} \\
\hline Age (Year) & Male & Female & Unknown & TOTAL & $\%$ \\
\hline$\leq 4$ & 63 & 52 & 16 & $\mathbf{1 3 1}$ & 14.09 \\
$5-9$ & 56 & 52 & 3 & $\mathbf{1 1 1}$ & 11.94 \\
$10-19$ & 99 & 76 & - & $\mathbf{1 7 5}$ & 18.82 \\
$20-29$ & 93 & 123 & 3 & $\mathbf{2 1 9}$ & 23.55 \\
$30-39$ & 56 & 71 & 1 & $\mathbf{1 2 8}$ & 13.76 \\
$40-49$ & 29 & 36 & 1 & $\mathbf{6 6}$ & 7.10 \\
$50-59$ & 5 & 24 & - & $\mathbf{2 9}$ & 3.11 \\
$60-69$ & 14 & 21 & - & $\mathbf{3 5}$ & 3.76 \\
$\geq 70$ & 5 & 3 & - & $\mathbf{8}$ & 0.86 \\
Unknown & 3 & 9 & 16 & $\mathbf{2 8}$ & 3.01 \\
\hline TOTAL & $\mathbf{4 2 3}$ & $\mathbf{4 6 7}$ & $\mathbf{4 0}$ & $\mathbf{9 3 0}$ & $\mathbf{1 0 0}$ \\
\hline \% & $\mathbf{4 5 . 4 8}$ & $\mathbf{5 0 . 2 2}$ & $\mathbf{4 . 3 0}$ & & \\
\hline Pregnancy & $\mathbf{n}$ & & &
\end{tabular}

Pregnancy (n:19)

\begin{tabular}{lll} 
Trimester I & 2 & 10.52 \\
Trimester II & 8 & 42.11 \\
Trimester III & 9 & 47.37 \\
\hline
\end{tabular}

\section{Time elapsed until admission (h) [n: 253]}

$\begin{array}{lcc}<1 & 71 & 28.06 \\ 1-3 & 143 & 56.52 \\ 4-6 & 18 & 7.12 \\ 7-24 & 17 & 6.72 \\ >24 & 4 & 1.58\end{array}$

Admission center

\begin{tabular}{lcc} 
Local hospital & 831 & 89.36 \\
Private medical center & 84 & 9.03 \\
Primary health center & 7 & 0.75 \\
Others & 8 & 0.86 \\
\hline
\end{tabular}

Table 2

The register is a database of all cases of scorpion stings according to symptoms of poisoning and frequency of the clinical symptoms reported in each incidence of poisoning. The records of healthcare organizations have shown localized

(77.9\%) and systemic symptoms (22\%) in the cases (145 out of 930). In addition, 177 out of all cases of scorpion stings were also classified as no, mild, moderate, and severe poisoning, by health professionals

\begin{tabular}{|c|c|c|}
\hline Clinic symptoms & $\begin{array}{l}\text { Number of patients } \\
\text { (n: 145) }\end{array}$ & $(\%)$ \\
\hline Local symptoms & 113 & 77.93 \\
\hline Pain & 69 & 47.58 \\
\hline Hyperemia & 35 & 24.14 \\
\hline Edema & 34 & 23.45 \\
\hline Numbness & 9 & 6.21 \\
\hline Burning & 2 & 1.38 \\
\hline Itching & 1 & 0.69 \\
\hline Induration & 1 & 0.69 \\
\hline Systemic symptoms & 32 & 22.07 \\
\hline Nausea & 7 & 4.82 \\
\hline Tachycardia & 4 & 2.76 \\
\hline Vomiting & 4 & 2.76 \\
\hline Tremor & 4 & 2.76 \\
\hline Hyperthermia & 3 & 2.07 \\
\hline Lethargy & 3 & 2.07 \\
\hline Hypertension & 2 & 1.38 \\
\hline Bradycardia & 2 & 1.38 \\
\hline Hypotension & 2 & 1.38 \\
\hline Agitation & 2 & 1.38 \\
\hline Sweating & 2 & 1.38 \\
\hline Spasm & 2 & 1.38 \\
\hline Loss of consciousness & 2 & 1.38 \\
\hline Pulmonary infusion & 1 & 0.69 \\
\hline Chest pain & 1 & 0.69 \\
\hline Abdominal pain & 1 & 0.69 \\
\hline Sialorrhea & 1 & 0.69 \\
\hline Stupor & 1 & 0.69 \\
\hline Abdominal distention & 1 & 0.69 \\
\hline Fasciculation & 1 & 0.69 \\
\hline Confusion & 1 & 0.69 \\
\hline Convulsion & 1 & 0.69 \\
\hline Feel cold & 1 & 0.69 \\
\hline \multicolumn{3}{|c|}{ Clinical assessment of envenoming (n: 177) } \\
\hline No envenomation & 2 & 1.13 \\
\hline Mild envenomation & 60 & 33.90 \\
\hline Moderate envenomation & 107 & 60.45 \\
\hline Severe envenomation & 8 & 4.52 \\
\hline \multicolumn{3}{|l|}{ Treatment (n: 103) } \\
\hline Symptomatic & 60 & 58.25 \\
\hline Symptomatic and antivenom & 9 & 8.75 \\
\hline Antivenom & 34 & 33.00 \\
\hline
\end{tabular}


hyperemia (24.14\%), edema (23.45\%) and numbness $(6.21 \%)$. When we evaluated systemic symptoms observed in scorpion stings, the most frequent findings we noted in descending order are: nausea $(4.82 \%)$, tachycardia, vomiting and shivering $(2.76 \%)$, hyperthermia and lethargy $(2.07 \%)$. In addition, the highest rate of poisoning was clinically classified as moderate $(60.45 \%)$, followed by mild $(33.90 \%)$, according to notifications by the health professionals, as shown in Table 2. The data showed us that $58.25 \%$ of the stung persons were treated symptomatically, $8.75 \%$ symptomatically and with antivenin, and finally, $33 \%$ with antivenin in healthcare facilities.

\section{DISCUSSION}

According to recent study, north-Saharan Africa, Sahelian Africa, South Africa, Near and Middle-East, South India, Mexico and South America, east of the Andes areas involve an at risk population of 2.3 billion, which 1.2 million leading to more than 3250 deaths. Therefore, scorpion poisoning cases are still a considerable public health problem in all regions of the country ${ }^{8}$.

There have been only few epidemiological records, instances of clinical research and case reports on Mesobuthus eupeus, Androctonus crassicauda scorpion stings and scorpion stings in children in the West and southeastern parts of Turkey 3,6,7,23,27,28,36. There is also only one study about the general scorpion sting incidence covering all geographical regions of Turkey ${ }^{29}$. However, as far as we know, the present is the first epidemiological and clinical study on scorpions and scorpion stings covering all geographical regions of Turkey.

In this study, a retrospective analysis of poisoning incidences recorded in NPIC showed us a total number of 930 inquiries related to scorpion stings within a period of ten years (1995-2004). Recently in a study, a total number of 24,261 scorpion sting cases were reported to have occurred in 2005, most of which occurred in the Southeastern Anatolia, Mediterranean Sea and Aegean regions ${ }^{29}$. In our study, most scorpion stings were notified in the Central Anatolia region and in the Marmara region. Our results suggest that medical professionals have more knowledge and experience regarding the treatment of scorpion stings in Southeastern Anatolia, Mediterranean Sea, and Aegean regions because most of the cases occurred in these areas.

In Morocco, the majority of victims (91.4\%) arrived at the hospital in less than three hours after the accident ${ }^{37}$. In another study, in Saudi Arabia $^{22,}$ the majority of cases were reported in primary health care centers $(85.5 \%)$ and hospitals $(10.50 \%)$. However, in the present study, $89.39 \%$ of patients attended local hospitals within three hours $(84.58 \%)$ of the sting. The reason for this is considered to be that the people of the region know what to do and immediately look for the treatment of scorpion sting, because they have more experience of scorpion stings.

In warm climates, scorpions become more active. Therefore, the highest incidence of scorpion stings took place in the warmest months of the year in different countries such as $\operatorname{Iran}^{33,35}$, Mexico ${ }^{9,11,25}$, Morocco ${ }^{1}$, Egypt $^{16}$, Argentina ${ }^{13}$, Saudi Arabia ${ }^{21}$, Brazil $^{30}$ and Turkey ${ }^{7,29}$. In parallel, we found that scorpion stings are frequent during hot months (MaySeptember), with a maximum frequency in July.

In Mexico, Saudi Arabia and Argentina, epidemiological studies showed that most scorpion stings were seen in males ${ }^{9,13,21}$. In our study, scorpion stings were seen mostly in females (50.22\%). However, the most scorpion stings were seen in males in the $0-19$ age group. The ratio between age groups and gender was statistically significant $(p<0.01)$. JARRAR \& AL-ROWAILY ${ }^{22}$ stated that the majority of scorpion stings occurred in people aged between 20 and 29 years old, during work. They explained that this result is associated with outdoor activities. Our study has similar results. The reason for this is considered to be the fact that the young population in this region work in agricultural fields during the summer period. In Morocco, the highest sting incidence reported, $60 \%$, involved victims younger than 30 years old ${ }^{37,38}$. Another study on scorpion stings in Mexico reported that $77 \%$ of all accidents occurred among people younger than 30 years old ${ }^{12}$. In this study, similar results have been found for the same age group.

Important scorpion species threatening public health in Turkey are identified as Androcronus crassicauda, Leiurus quinquestratus, Mesobuthus gibousus and M. eupeus of the Buthidae family ${ }^{27-29}$. The venom of the Buthidae family has neurotoxic effects. The neurotoxic peptides in the venom are responsible for the symptoms that present during poisoning, by interacting with ion channels. Ion channels are gated pores of which gating may be intrinsic or regulated by ligand binding or changes in the voltage gradient across the membrane ${ }^{15}$. Localized or systemic clinical effects could appear related to the species of scorpion, feeding state, structure of the telson and amount of venom injected, number of stings, time of admission to hospital, sensitivity of patient, age, weight and climate of the region ${ }^{13,14,18,33}$.

According to literature on the clinical and epidemiological aspects of scorpion stings in Turkey, poisoning was characterized by localized and systemic symptoms. The most common symptoms reported were localized pain, edema, hyperemia, swelling, burning, numbness and itching, and the systemic symptoms were a dry mouth, thirst, sweating, hypotension, hypertension, cramps and shivering, nausea, vomiting, difficulty in breathing, tachycardia, sialorrhoea, restlessness, hemolyticuremic syndrome, cyanosis, cardiac failure and/or acute pulmonary edema and death $3,6,7,10,23,24,27,28,31,36$.

Scorpion stings can cause similar clinic manifestations in many countries of Central and South America, North Africa, the Middle East and Asia ${ }^{5,9,13,21,30,37,38}$. In our study, the most common symptoms reported were: localized pain $(47.58 \%)$, hyperemia $(24.14 \%)$, edema $(23.45 \%)$ and numbness $(6.21 \%)$. Nausea $(4.82 \%)$, tachycardia, vomiting and shivering $(2.76 \%)$, hyperthermia and lethargy $(2.07 \%)$ were also observed as systemic symptoms. In our research, cases (177 out of 930) were also classified as mild (33.9\%), moderate $(60.45 \%)$, and severe poisoning (4.52\%). In agreement with SHAHBAZZADEH et $a l .{ }^{35}$ and CHOWELL et al. ${ }^{9}$ we observed most cases of poisoning as mild and moderate.

The only specific treatment for scorpion poisoning is the speciesspecific antivenin. Antivenin is widely used in cases of scorpion stings. However, its efficacy is still controversial, particularly in the case of mild and moderate poisoning, although allergic reactions have never been reported $^{2,4,18-20,32}$. In Turkey, the Refik Saydam Public Health Agency is responsible for the manufacturing of antivenin produced from $A$. crassicauda venom. This antivenin has been used for the treatment of all scorpion sting cases in Turkey ${ }^{3}$. In the present study, most of the 
patients (58\%) were treated symptomatically, whereas only $33 \%$ of the cases were treated with antivenin.

In conclusion, we reported on the epidemiological and clinical characteristics of scorpion poisoning throughout the country of Turkey during the period 1995-2004. We argue that in Turkey, public awareness campaigns and an increase in the number of healthcare facilities and health care professionals have kept lethalities due to poisoning to a minimum. All scorpion species with highly potent, mammal specific neurotoxins belong to the family Buthidae, which therefore has medical importance. Nevertheless, identifying the scorpion may be considered as a useful clinical and epidemiological tool in determining the incidence and risk of scorpion poisoning. Of course, it will be important to supply sufficient quality and quantity of antivenin to medical facilities in both rural and urban areas and to maintain a critical number of trained medical professionals in the regions where poisoning is seen.

\section{RESUMO}

\section{Picadas de escorpião na Turquia: aspectos epidemiológicos e clínicos entre os anos de 1995 e 2004}

Os mais importantes escorpiões que comprometem a saúde na Turquia são: Androctonus crassicauda, Leiurus quinquestriatus, Mesobuthus gibbosus e $M$. eupeus, todos eles pertencentes à família Buthidae. Os achados clínicos e epidemiológicos da picada de escorpiões na Turquia foram avaliados no período entre os anos de 1995 a 2004 baseados em dados do Centro Nacional de Informações de Envenenamentos (NPIC). Foram registrados 930 casos que ocorreram principalmente no mês de julho. A distribuição por sexo foi $50,22 \%$ femininos e $45,48 \%$ masculinos. Demonstrou-se que o grupo etário de 20 a 29 anos apresentou maior número de picadas de escorpião. A maior parte das picadas ocorreu na Anatólia Central e na região de Marmara, na Turquia. Os pacientes hospitalizados mostraram sinais localizados (dor, hiperemia, edema e confusão mental) e sistêmicos (hipertermia, náusea e vômitos, taquicardia, arrepios de frio e letargia), mas não houve notificação de letalidade. De acordo com os prontuários 33\% dos pacientes foram tratados com antiveneno nas unidades de saúde.

\section{REFERENCES}

1. Abourazzak S, Achour S, El Arqam L, Atmanı S, Chaoukı S, Semlalı I, et al. Epidemiological and clinical characteristics of scorpion stings in children in Fez, Morocco. J Venom Anim Toxins Incl Trop Dis. 2009;15:255-67.

2. Abroug F, El-Atrous S, Nouira S, Haguiga H, Touzı N, Bouchouch S. Serotherapy in scorpion envenomation: a randomised controlled trial. Lancet. 1999;354:906-9.

3. Adiguzel S, Ozkan O, Inceoglu B. Epidemiological and clinical characteristics of scorpionism in children in Sanliurfa, Turkey. Toxicon. 2007;49:875-80.

4. Akdur O, Ikızcelı I, Avsarogulları L, Ozkan S, Sozuer EM. Acute urticaria due to scorpion antivenom administration: a case report. Akademik Acil Tip Dergisi. 2007;5:39-40.

5. Al-Sadoon MK, Jarrar BM. Epidemiological study of scorpion stings in Saudi Arabia between 1993 and 1997. J Venom Anim Toxins Incl Trop Dis. 2003;9:54-64.

6. Altınkaynak S, Ertekın V, Alp H. Scorpion envenomation in children. Turk. Arch. Ped. 2002;37:48-54.

7. Bosnak M, Ece A, Yolbas I, Bosnak V, Kaplan M, Gurkan F. Scorpion sting envenomation in children in southeast Turkey. Wilderness Environ Med. 2009;20:118-24.
8. Chippaux JP, Goyffon, M. Epidemiology of scorpionism: a global appraisal. Acta Trop. 2008;107:71-9.

9. Chowell G, Diaz-Duenas P, Bustos-Saldana R, Aleman Mireles A, Fet V. Epidemiological and clinical characteristics of scorpionism in Colima, Mexico (2000-2001). Toxicon. 2006;47:753-8

10. Dayar E, Gorsel G, Dursun O, Kardelen F, Uguz A. Akrep sokması sonrası ciddi aritmi ve miyokard iskemisi: Olgu sunumu (Poster presentation). 50. Milli Pediatri Kongresi. 2006, 8-12 Kas1m. World of Wonders/Kremlin Palace, Aksu, Antalya. Available from http://www.millipediatri.org.tr/bildiriler/PP-415.htm. 2006.

11. Dehesa-Davila M. Epidemiological characteristics of scorpion sting in Leon, Guanajuato, Mexico. Toxicon. 1989;27:281-6.

12. Dehesa-Davıla M, Possanı LD. Scorpionism and serotherapy in Mexico. Toxicon. 1994;32:1015-8.

13. De Roodt AR, Garcia SI, Salomon OD, Segre L, Dolab JA, Funes RF, et al. Epidemiological and clinical aspects of scorpionism by Tityus trivittatus in Argentina. Toxicon. 2003;41:971-7.

14. Dittrich K, Power AP, Smith NA. Scorpion sting syndrome - a ten year experience. Ann Saudi Med. 1995;15:148-55.

15. Du Plessisa LH, Elgara D, Du Plessisb JL. Southern African scorpion toxins: an overview. Toxicon. 2008;51:1-9.

16. Farghly WM, Alı FA. A clinical and neurophysiological study of scorpion envenomation in Assiut, Upper Egypt. Acta Paediatr. 1999;88:290-4.

17. Gazarıan KG, Gazarıan T, Hernandez R, Possanı LD. Immunology of scorpion toxins and perspectives for generation of anti-venom vaccines. Vaccine. 2005;23:3357-68.

18. Hammoud1-Trıkı D, Ferquel E, Robbe-Vıncent A, Bon C, Choumet V, Laraba-Djebarı F. Epidemiological data, clinical admission gradation and biological quantification by ELISA of scorpion envenomations in Algeria: effect of immunotherapy. Trans R Soc Trop Med Hyg. 2004;98:240-50.

19. Holve S. Venomous spiders, snakes, and scorpions in the United States. Pediatr Ann. 2009;38:210-7.

20. Ismail M. Treatment of the scorpion envenoming syndrome: 12-years experience with serotherapy. Int J Antimicrob Agents. 2003;21:170-4.

21. Jahan S, Mohammed Al Sargul A, Abdul Rahım Hamed S. Scorpion stings in Qassim, Saudi Arabia - A 5-year surveillance report. Toxicon. 2007;50:302-5.

22. Jarrar BM, Al-Rowa1ly MA. Epidemiological aspects of scorpion stings in Al-Jouf Province, Saudi Arabia. Ann Saudi Med. 2008;28:183-7.

23. Karakurt C, Kocak G. Toxic myocarditis after scorpion envenomation: case report. J Inonu Univ Med Fac. 2007; 14:61-3.

24. Mocan H, Mocan M, Kaynar K. Haemolytic-uraemic syndrome following a scorpion sting. Nephrol Dial Transplantation. 1998;13:2639-40.

25. Osnaya-Romero N, De Jesus Medina-Hernández T, Flores-Hernández SS, León-Rojas G. Clinical symptoms observed in children envenomated by scorpion stings, at the children's hospital from the State of Morelos, Mexico. Toxicon. 2001;39:781-5.

26. Oukkachea N, Rossoa J, Alamı M, Ghalımb N, Saıle R, Hasar M, et al. New analysis of the toxic compounds from the Androctonus mauretanicus mauretanicus scorpion venom. Toxicon. 2008;51:835-52.

27. Ozkan O, Adıguzel S, Yakıstıran S, Cesaretlı Y, Orman M, Karaer KZ. Androctonus crassicauda (Olivier 1807) scorpionism in the Sanliurfa Provinces of Turkey. Turkiye Parasitol Derg. 2006;30:239-45. 
28. Ozkan O, Kat I. Mesobuthus eupeus scorpionism in Sanliurfa region of Turkey. J Venom Anim Toxins Incl Trop Dis. 2005;11:479-91.

29. Ozkan O, Uzun R, Adıgüzel S, Cesaretli Y, Ertek M. Evaluation of scorpion sting incidence in Turkey. J Venom Anim Toxins Incl Trop Dis. 2008;14:128-40.

30. Pardal PP, Castro LC, Jennıngs E, Pardal JS, Monteıro MR. Aspectos epidemiológicos e clínicos do escorpionismo na região de Santarem, Pará, Brasil. Rev Soc Bras Med Trop. 2003;36:349-53.

31. Pırgon O, Sert A, Atabek ME, Tokgoz H. The follow-up by cardiac troponin I of cardiac involvement in a case with scorpion envonoming. Selçuk Tip Derg. 2005;21(3):88-90.

32. Possan1 LD. Antivenom for scorpion sting. Lancet. 2000;355:66-7.

33. Radmanesh M. Androctonus crassicauda sting and its clinical study in Iran. J Trop Med Hyg. 1990;93:323-6.
34. Samı-Merah S, Hammoudı-Trıkı D, Martın-Eauclaıre MF, Laraba-Djebarı F. Combination of two antibody fragments $\mathrm{F}(\mathrm{ab})_{2} / \mathrm{Fab}$ : an alternative for scorpion envenoming treatment. Int Immunopharm. 2008;8:1386-94.

35. Shahbazzadeh D, Amırkhanı A, Djadıd ND, Bigdelı S, Akbarı A, Aharı H, et al. Epidemiological and clinical survey of scorpionism in Khuzestan province, Iran (2003). Toxicon. 2009;53:454-9.

36. Soker M, Haspolat K, Güneydoğu ve Anadolu bölgesinde çocuklarda akrep sokması: 64 vakanın değerlendirilmesi. Çocuk Sağlığı ve Hastalıkları Dergisi. 2000;43:43-50.

37. Soulaymanı BR, Idrıssı M, Tamım O, Semlalı I, Mokhtarı A, Tayeb M, et al. Scorpion stings in one province of Morocco: epidemiological, clinical and prognosis aspects. J Venom Anim Toxins Incl Trop Dis. 2007;13:462-71.

38. Touloun O, Slımanı T, Boumezzough A. Epidemiological survey of scorpion envenomation in southwestern Morocco. J Venom Anim Toxins Incl Trop Dis. 2001;7:199-218.

Received: 5 January 2010

Accepted: 6 May 2010 